\title{
NEW LOCALITY RECORDS FOR SOME RARE MOSSES IN TASMANIA
}

\author{
by P.J. Dalton
}

(with two tables, one text-figure and one plate)

Dalton, P.J., 1998 (31:xii): New locality records for some rare mosses in Tasmania. Pap. Proc. R. Soc. Tasm. 132: 41-45.

ISSN 0080-4703. https://doi.org/10.26749/rstpp.132.41 School of Plant Science, University of Tasmania, GPO Box 252-55,

Hobart, Tasmania, Australia 7001.

Further records of occurrence of four rare mosses, Seligeria cardotii R.Br., Calomnion complanatum (Hook.f. et Wils.) Lindb., Ephemeropsis trentepohlioides (Rem.) Sainsb. and Papillaria flexicaulis (Wils.) Jaeg., are provided as well as notes on their habitat and distinguishing features.

Key Words: mosses, Seligeria, Calomnion, Ephemeropsis, Papillaria, Tasmania.

\section{INTRODUCTION}

There have been more than 640 species of bryophytes recorded for Tasmania, comprised of 282 hepatic species (Ratkowsky 1987) and 361 moss species (Dalton et al. 1991). This number of species is significant when compared to other groups of land plants and, therefore, the bryophytes represent a major component of the flora (table 1).

Since the publication of an annotated checklist of Tasmanian mosses (Dalton et al. 1991), further collecting, and taxonomic and ecological research on the flora have continued, resulting in some additions and further distributional records for many species. Moscal \& Kirkpatrick (1997) presented distribution maps of mosses and liverworts in Tasmania with the intention of establishing their reservation and conservation status. However, for a number of the rarer species data were not included, or information was based on old collections and/or literature records. In this paper, new records for the distribution of four interesting and rare mosses in Tasmania are reported, and their importance to the diversity of the bryoflora is discussed.

TABLE 1

The estimated number of native species in different plant groups

\begin{tabular}{lcc}
\hline & Species & \% endemics \\
\hline Lichens* $^{*}$ & 762 & - \\
Bryophytes $^{\dagger}$ (moss \& hepatic) & 643 & 8 \\
Pteridophytes $^{\ddagger}$ (ferns \& allies) & 98 & 5 \\
Gymnosperms $^{\ddagger}$ (conifers) & 11 & 80 \\
Angiosperms $^{\ddagger}:$ Monocots & 539 & 14 \\
Angiosperms $^{\ddagger}:$ Dicots & 943 & 25 \\
\hline
\end{tabular}

\footnotetext{
* Kantvilas 1994.

† Ratkowsky 1987 and Dalton et al. 1991.

$\ddagger$ Buchanan 1995 .
}

\section{METHODS}

This study is based on verified herbarium collections (CANB and $\mathrm{HO}$ ) and field collections made in Tasmania by the author. All new collections are deposited in the Tasmanian Herbarium (HO), with duplicates held in the author's private herbarium. Determination of species is based on comparisons with reliably identified reference material and/or literature descriptions. Scanning electron microscopy used one of the following procedures:

(1) fresh material observed in an ESEM Electro Scan 2020 in wet mode (cold stage), or

(2) fresh material fixed in $2 \%$ Osmium tetroxide, dehydrated in acetone series, rinsed twice in Hexamethyldisilazone (HMDS), air dried, sputter coated with gold and then observed under HIVAC in a ESEM Electro Scan 2020.

\section{RECORDS}

\section{Seligeria cardotii R. Br.}

This minute epilithic moss is the only species of the genus that has been recorded for Tasmania. Plants, which form a loose assemblage on limestone, are erect, up to $2 \mathrm{~mm}$ high and light green when moist. The leaves are linear with a prominent midrib which is narrow at the base but wider above. The mid-leaf cells are clear and rectangular in 2-3 rows each side of the midrib. A fuller description and illustration of the Tasmanian material has been presented by Dalton (1995).

This calcicolous moss was previously considered a species endemic to New Zealand (Sainsbury 1955), where it has a widespread distribution. The first record of it occurring in Tasmania was reported from Dogs Head Hill, Mole Creek, where it grew on damp limestone in dry sclerophyll forest (Dalton 1955). A new record (P.J. Dalton 94.220, 9.xii.1994) is reported from a similar substrate, moist calcareous rockface, but in a more protected habitat in refuge rainforest (Nothofagus cunninghamiilAtherosperma moschatum) in the upper part of the Junee Valley, adjacent to Mt Field National Park (fig. 1A). This species may have a greater distribution on suitable calcareous substrate in Tasmania, but it has possibly been overlooked due to its small size and specific substrate. 

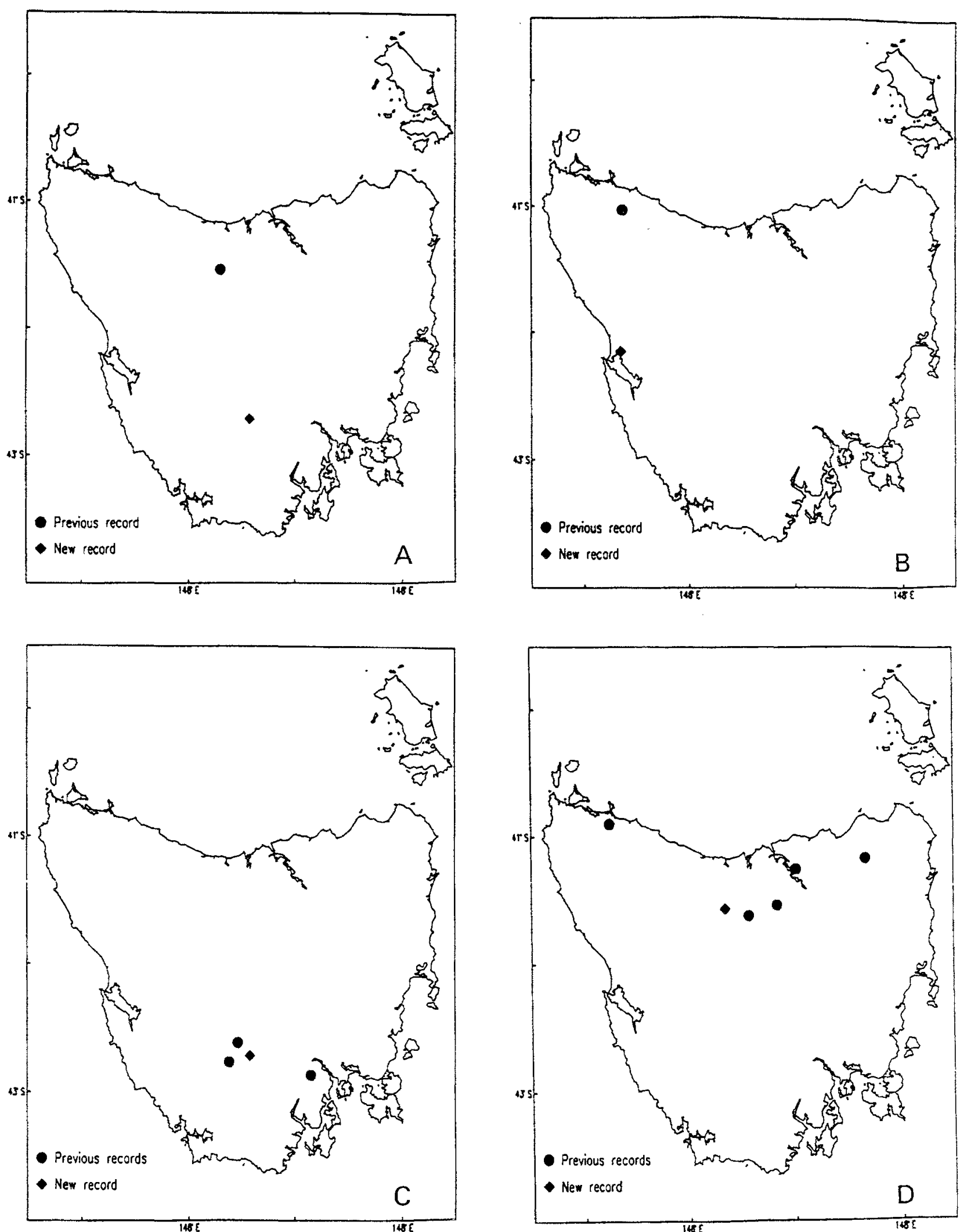

FIG. 1 - The distribution of (A) Seligeria cardotii, (B) Calomnion complanatum, (C) Ephemeropsis trentepohlioides, (D) Papillaria flexicaulis. 


\section{Calomnion complanatum (Hook. f. et Wils.) Lindb.}

This is the sole species of the genus in the Tasmanian flora and is characterised by simple shoots which bear leaves in three ranks in the upper part of the stem but are often denuded below. The leaves of the two lateral rows are oblong, while smaller orbicular leaves form a dorsal row (pl. 1A). There is a distinct midrib, which is percurrent, and the leaf margin varies from entire to slightly crenulate. A fuller description can be found in Vitt (1995), and Stone (1990) provided a detailed description of the persistent heterotrichous protonema.

The species was first recorded for Tasmania growing as an epiphyte on the fibrous trunk of Dicksonia antarctica beside the track at Dip Falls, near Stanley (Stone 1990), although Vitt (1995) reported a Tasmanian collection (NY) without locality made by Gunn. A new record (P.J. Dalton 95.18, 23.v.1995) is reported from the Hogarth Falls track, Strahan (fig. 1B), where it was growing on the trunk of a tree fern, which appears to be the preferred substrate. The leaves of $C$. complanatum are highly deciduous and probably act as vegetative propagules. It could be postulated that this may have aided the recent occurrence and distribution of the species at the two known localities, which are popular tourist destinations.

\section{Ephemeropsis trentepohlioides (Rem.) Sainsb.}

This moss is characterised by an extremely reduced gametophyte made up of a fine brownish filamentous protonema which could easily be overlooked in the field. It is readily recognised as a moss with the presence of minute setae (c. $2 \mathrm{~mm}$ long) bearing tiny erect capsules (pl. 1B), which arise from small perichaetial bracts. The calyptra is mitriform with a fringed base, and the outer peristome is short, with the 16 teeth bent back over the opened capsule when dry (pl. 1C). Spores are large, elongate and multicellular (pl. 1D). This is probably the most extraordinary moss in the flora and has been described by Willis (1953).

This unique epiphytic moss, which is widespread on both North and South Islands of New Zealand (Beever et al. 1992), was first recorded in Tasmania from the Florentine Valley (Willis 1953). A further collection from the same area was made by Norris (HO 93460) and, more recently, a collection from Myrtle Gully, Collinsvale (D. Glenny, pers. comm.). A new record (P. J. Dalton 94.215, 9.xii. 1994) is reported from the upper part of Junee Valley (fig. 1C), where the species was an abundant epiphyte on living and dead twigs of Atherosperma moschatum. It was most abundant at the edge of refuge rainforest, where light penetration is favourable.

\section{Papillaria flexicaulis (Wils.) Jaeg.}

This epiphytic species is characterised by long, slender, pendulous dull-green shoots. The leaves are narrowly triangular, imbricate and tightly appressed to the stem when dry (pl. 1E), but when moist rapidly stand at right angles to the stem. The nerve is faint and extends to three-quarters of the leaf. The cells are thomboidal throughout, and in the mid-leaf and above are densely papillose, with the papillae extending to the margins of the leaf (pl. 1F). A detailed description was given by Streimann (1991).

Three other species of Papillaria occur in Tasmania: $P$. flavolimbata is the commonest species, with robust yellowish-green shoots which often taper to very slender shoots. The leaves are extremely undulate, and the papillae do not extend to the margins of the leaf. $P$. crocera is a similar species, but the smooth cells at the margin of the leaf are shorter. $P$. nitens has finer, softer shoots, and the leaf cells are not obscured with dense papillae as in the previous species.

Papillaria flexicaulis is a widespread moss on the Australian mainland and would appear to reach its southern limit in northern Tasmania (Streimann 1991). Nine collections have been recorded, and eight of these were made in the late 19 th century (Circular Head, Westbury, Deloraine and East Tamar). The impact of human occupation at these localities during the past century would cast doubt on the continuing survival of the species. The only previous collection during the last 100 years was made in 1974, in moist eucalypt forest near Scottsdale (Norris HO94217). A new record (P.J. Dalton 94.43, 28.i.1994) is reported from Sassafras Ridge, Mole Creek (fig. 1D), where the species occurred as a pendulous epiphyte on Pomaderris apetala and Olearia argophylla in eucalypt forest.

\section{DISCUSSION}

The mosses Seligeria cardotii, Calomnion complanatum, Ephemeropsis trentepohlioides and Papillaria flexicaulis have limited distribution in the Tasmanian vegetation. In contrast, all four species are widely distributed on both North and South Islands of New Zealand, while P. flexicaulis is the only species with widespread distribution on mainland Australia. There are strong affinities of the Tasmanian bryoflora to New Zealand and southeastern Australia (Victoria and NSW) and, in the case of the mosses, as much as threequarters is shared with those areas (Scott \& Stone 1976, Beever et al. 1992).

An alternative comparison of the bryofloras can be made by determining the diversity or richness, which can be expressed as the number (genera and/or species) per logarithmic area. The diversity of the Tasmanian bryoflora compared with floras in other temperate regions is evaluated in table 2. These numbers are approximations only, since taxonomic revisions and biogeographic studies will inevitably result in further changes. The species diversity of mosses in Tasmania is less than in southeastern Australia (Victoria and NSW) and much less than in New Zealand. However, the hepatics are considerably more diverse than those of Victoria but, like the mosses, are markedly less so than in New Zealand. Of the Gondwanan land masses (i.e. New Zealand, southern Australia, Tasmania and southern Africa), New Zealand contains the greatest diversity of bryophytes, which is in agreement with previous comparative studies (Fife 1985).

The diversity of the Tasmanian mosses may not be as impressive as other floras. Nevertheless, the specialised habitats that are occupied by such epiphytic species as $C$. complanatum, E. trentepohlioides and $P$. flexicaulis and the epilithic species $S$. cardotii are an important component of the floristics of the Tasmanian vegetation. Three of the species are the sole representatives of genera in Tasmania, and all four occupy habitats and substrates that may be 

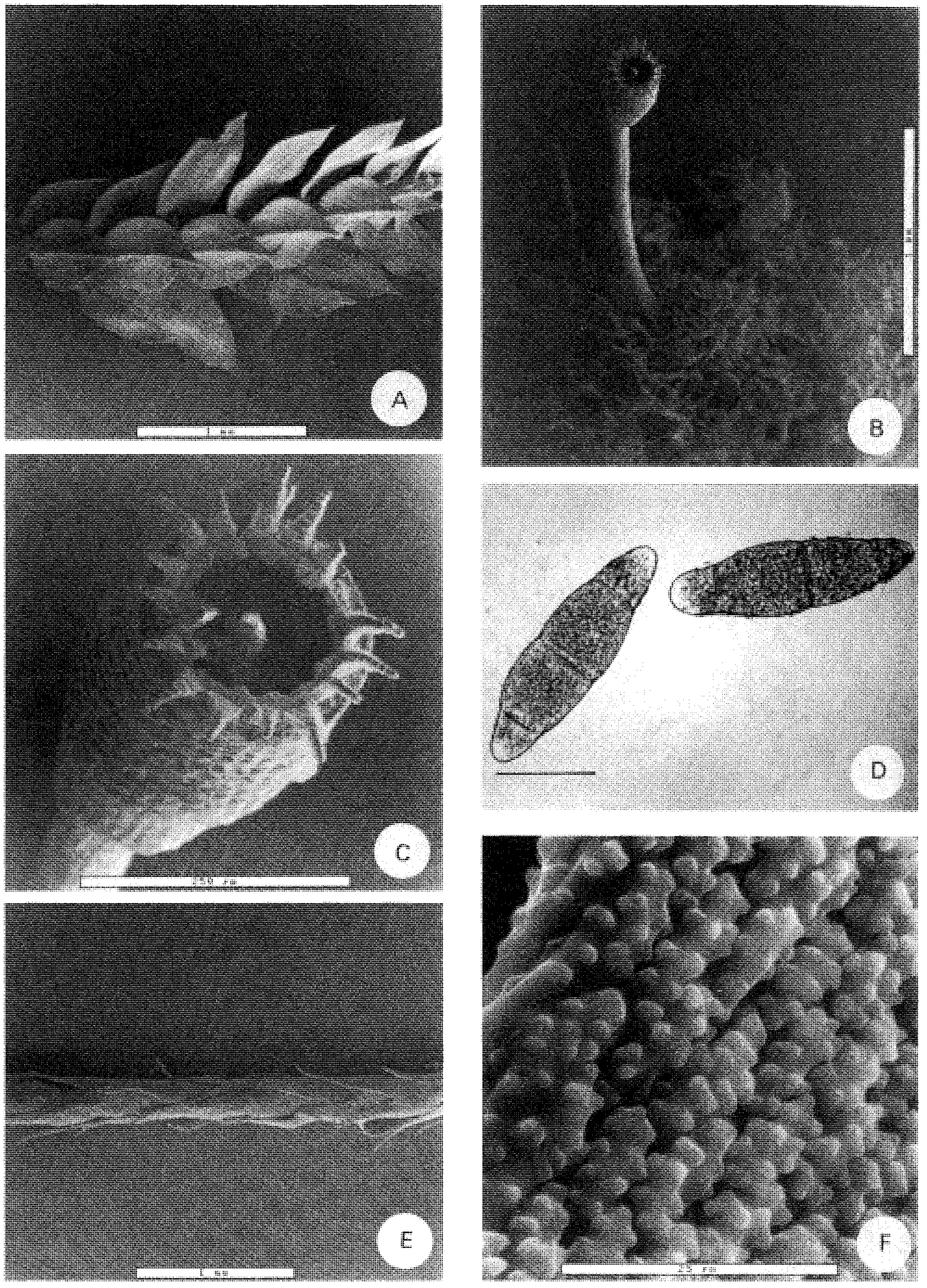

PLATE I

(A) ESEM (Hivac) whole shoot of Calomnion complanatum, (B) ESEM (Hivac) whole shoot with capsule of Ephemerophsis trentepohlioides, (C) ESEM (Hivac) capsule with peristome of E. trentepohlioides, (D) LM Spores of E. trentepohlioides, Scale bar $50 \mu \mathrm{m}$, (E) ESEM (Hivac) whole shoot of Papillaria flexicaulis, (F) ESEM (wet mode) leaf surface with papillae of P. flexicaulis. 
TABLE 2

The number of genera and species of mosses and hepatics in comparable temperate geographic regions

\begin{tabular}{lcccc}
\hline $\begin{array}{l}\text { Geographic region } \\
\text { * }\end{array}$ & $\begin{array}{l}\text { No. of } \\
\text { species }\end{array}$ & $\begin{array}{c}\text { No. of } \\
\text { genera }\end{array}$ & $\begin{array}{c}\text { No. of species } \\
\text { per ln. }\left(\mathrm{km}^{2}\right)\end{array}$ & $\begin{array}{c}\text { No. of genera } \\
\text { per ln. }\left(\mathrm{km}^{2}\right)\end{array}$ \\
\hline $\begin{array}{l}\text { Mosses } \\
\text { Tasmania }\end{array}$ & & & & \\
NSW $^{2}$ & 361 & 141 & 32.4 & 12.7 \\
Victoria $^{3}$ & 527 & 171 & 38.8 & 12.6 \\
South Aust. $^{4}$ & 500 & 150 & 40.5 & 12.2 \\
West Aust. $^{5}$ & 179 & 79 & 13.0 & 5.7 \\
New Zealand $^{6}$ & 192 & 78 & 13.0 & 5.3 \\
Europe $^{7}$ & 523 & 208 & 41.8 & 16.6 \\
British Isles $^{8}$ & 1052 & 232 & 65.4 & 13.4 \\
southern Africa $^{9}$ & 692 & 175 & 54.7 & 12.9 \\
& 591 & 191 & 39.9 & \\
Hepatics $_{\text {Tasmania }}{ }^{10}$ & & & & 8.6 \\
Victoria $^{3}$ & & & & 6.8 \\
New Zealand $^{11}$ & 282 & 96 & 25.3 & 11.4 \\
US \& Canada $^{7}$ & 230 & 84 & 18.6 & 6.7 \\
Europe $^{7}$ & 569 & 142 & 45.5 & 6.5 \\
southern Africa $^{9}$ & 500 & 129 & 29.8 & 6.2 \\
\hline
\end{tabular}

* (1) Dalton et al. 1991, (2) Ramsay 1984, (3) Cropper et al. 1991, (4) Catcheside 1980, (5) Stoneburner et al. 1993, (6) Fife 1995, (7) Fife 1985, (8) Smith 1980, (9) Magill \& Schelpe 1979, (10) Ratkowsky 1987, (11) Glenny, pers. comm. 1995 (unpubl. checklist).

vulnerable in much of the vegetation. Therefore, further studies are needed to identify the distribution of these species as well as other rare or less well-documented bryophytes, in order to maintain our knowledge of the diversity of the bryoflora in Tasmania.

\section{ACKNOWLEDGEMENTS}

I thank Michael Lichon and Dr Greg Jordan for field assistance, Wieslaw Jablonski of the Central Science Laboratory, University of Tasmania, for taking the SEM photographs and Greg Dutkowski for help in producing the distribution maps.

\section{REFERENCES}

BeEver, J., Allison, K.K. \& ChILd, J., 1992: THE MOSSES OF NEW ZEALAND. University of Otago Press, Dunedin.

BUCHANAN, A.M., 1995: A census of the vascular plants of Tasmania and index to The Student's Flora of Tasmania. Occ. Publ. Tasm. Herb. 5.

CATcheside, D.G., 1980: MOSSES OF SOUTH AUSTRALIA. Government Printer, Adelaide.

Cropper, S.C., Tonkinson, D.A. \& SCott, G.A.M., 1991: $A$ CENSUS OF VICTORIAN BRYOPHYTES. Dep. of Conservation and Environment, Victoria.

Dalton, P.J., 1995: Seligeria cardotii R. Br., a new moss record for Tasmania. NZ J. Bot. 33: 143-145.

Dalton, P.J., Seppelt, R.D. \& Buchanan, A.M., 1991: An annotated checklist of Tasmanian Mosses. In Banks, M.R. et al. (Eds): ASPECTS OF TASMANIAN BOTANY - A TRIBUTE TO WINIFRED CURTIS. Royal Society of Tasmania: $15-32$.
Fyfe, A.J., 1985: Biosystematics of the crytogamic flora of New Zealand: Bryophytes. NZ J. Bot. 23: 645-662.

Fife. A.J., 1995: Checklist of the mosses of New Zealand. Bryologist 98(3): 313-337.

Kantvilas, G., 1994: A revised checklist of the Tasmanian lichen flora. Muelleria 8: 155-175.

MAGILL, R.E. \& SCHELPE, E.A., 1979: The bryophytes of southern Africa. An annotated checklist. Mem. Bot. Surv. S. Afr. 43.

Moscal, A. \& KirKPatrick, J.B., 1997: ATLAS OF MOSSES AND LIVERWORTS IN TASMANIA. Tasmania Conservation Trust Inc., Hobart.

Ramsay, H.P., 1984: Census of New South Wales mosses. Telopea 2(5): 455-533

RaTowsKY, D.A., 1987: Checklist of the Tasmanian liverworts. Pap. Proc. R. Soc. Tasm. 121: 153-158.

SaINSBury, G.O.K., 1955: A handbook of the New Zealand mosses. Bull. R. Soc. NZ 5.

Scott, G.A.M. \& Stone, I.G., 1976: THE MOSSES OF SOUTHERN AUSTRALIA. Academic Press, London.

SMITH, A.J.E., 1980: THE MOSS FLORA OF BRITAIN AND IRELAND. Cambridge University Press, Cambridge.

Stone, I.G., 1990: Nomenclatural changes and new moss record in Australia: including a description of the protonema of Calomnion. J. Bryol. 16: 261-273.

Stoneburner, A., Wyatt, R., Catcheside, D.G. \& Stone, I.G., 1993: Census of the mosses of Western Australia. Bryologist 96(1): 86-101.

Streimann, H., 1991: Taxonomic studies on Australian Meteoriaceae (Musci) I. Introduction and the genus Papillaria. J. Hattori Bot. Lab. 69: 203-256.

VITT, D.H., 1995: The genus Calomnion (Bryopsida): Taxonomy, phylogeny and biogeography. Bryologist 98(3): 338-358.

WILLIS, J.H., 1953: Nemataceae, a moss family new to Australia. Nature 172: 127-128.

(accepted 5 May 1998) 